\title{
Factors Influencing Non-Performing Loans in Commercial Banks: The Case of Banks in Selangor
}

\author{
Uma Murthy ${ }^{1}$, Naail Mohammed Kamil ${ }^{1}$, Paul Anthony Mariadas ${ }^{1} \&$ Dilashenyi Devi ${ }^{1}$ \\ ${ }^{1}$ Global Leadership Research Unit, Faculty of Business, Accountancy and Management, SEGi University, \\ Malaysia
}

Correspondence: Uma Murthy, Global Leadership Research Unit, Faculty of Business, Accountancy and Management, SEGi University, Malaysia. E-mail: umamurthy@segi.edu.my

Received: October 24, 2016

doi:10.5539/ijbm.v12n2p246
Accepted: January 20, 2017 Online Published: January 26, 2017

URL: http://dx.doi.org/10.5539/ijbm.v12n2p246

\begin{abstract}
Non-performing loans (NPLs) is a worldwide issue that affects financial markets stability in general and banking industry viability in particular. This study examines the factors influencing non-performing loans in commercial banks in Selangor state of Malaysia. Based on gaps in extant literature, four (4) independent variables comprising standard of living, economy of the country, consumers' income and bank interest rates are hypothesized to exert statistically significant influences on the dependent variable, NPLs. A quantitative research approach was employed in this research. 200 respondents were sampled for this study employing stratified random sampling technique. Employing multiple regression analysis (MRA) using SPSS software, the findings showed that out of the four (4) hypothesized relationships of the research, three (3) were supported whilst one was not. In particular, it was shown that consumers' income, economy of the country and bank interest rates statistically influence non-performing loans in commercial banks in Selangor state of Malaysia. However, there was no enough evidence to support the claim that standard of living can statistically influence non-performing loans in commercial banks in Selangor. Several implications from the research were further discussed.
\end{abstract}

Keywords: non-performing loans, commercial banks, Selangor

\section{Introduction}

Non-performing loans (NPL) is a worldwide issue that affects financial markets stability in general and banking industry viability in particular. The net non-performing loan (NPL) ratio in the banking system since the Asian financial crisis has gradually been in decline from $13.6 \%$ in December 1998 to $2.8 \%$ in May 2008. Government intervention to non-performing loan recovery strategies have contributed significantly in the decline. The Malaysian government and banks have succeeded in removing the non-performing loans (NPL) from banks Balance Sheet. The Malaysian government has taken responsive actions to solve the financial problems through the creation of the Corporate Debt Restructuring Committee (CRDC), Danamodal, an organization for injecting government funds and Danaharta, an organization for purchasing non-performing loans. In addition, full attention from banks managements on the best practices in lending funds and its continuous improvement are required to support the growing economy of Malaysia. This crucial practices will hopefully reduce, if not eliminate non-performing loans in the country.

The objectives of this paper is identify and review the economic factors that contribute to non-performing loan, to expound the impact of nonperforming loan on the performance of financial institutions and to examine the effectiveness of the recovery strategies implemented to the non-performing loans (NPL) performance.

This paper will review the studies that focus on two foreign banks in Malaysia; HSBC Bank Malaysia Berhad (HSBC) and RHB (RHB Bank) as well as two domestic banks; Maybank Berhad (MBB) and Public Bank Berhad (PBB). This paper will also look into Bank Negara Malaysia and the Danaharta.

Further, this research will also make a comparison between domestic banks and foreign banks on the impact of non-performing loan (NPL) on their profitability. The non-performing loan (NPL) issue is often cited as one of the potential risks that may cause economic and financial instability in Malaysia. Non-performing loans (NPL) brought some banks in Asia to bankruptcies during the crises in the 1990s. According to the Financial Stability Institute, addressing the problems of non-performing loan (NPL) is a continuing challenge. Andrew Crockett 
(2003) argues that initially non-performing loans (NPL) may not seem to have a serious negative effect. Banks remain liquid, and depositors retain their confidence in the system. Over time, however, the size of the problem is growing, especially if banks are allowed to accrue interest on their non-performing loan (NPL).

From articles review, this research will identify which economic factors contribute to the highest portion of non-performing loan (NPL) and also their impacts on financial performance of financial institutions in Malaysia. In additional to that, it will identify the recovery strategies that have been implemented by the government to achieve the aforementioned objectives.

This research is showed by the subsequent questions; (1) what is the relationship between bank customers' standard of living and non-performing loan in Malaysian context? (2) what is the relationship between bank customers' income and non-performing loan in the Malaysian context? (3) what is the relationship between the Malaysian economy and non-performing loan in the Malaysian context? and (4) what is the relationship between banks interest rate and non-performing loan in the Malaysian context?

To seek the answers to these questions, this research will be organized into five (5) sections. Section one captures the introduction, section two discusses review of updated literatures, section three (3) highlights the methodology employed in analyzing empirical data for this research, section four (4) discusses data collection and analysis whilst, section five (5) provides the conclusion and recommendations, as well as the contributions and limitations of the research.

\section{Literature Review}

\subsection{The Definition of Non-Performing Loans}

The most common international recognized definition of non-performing loan, known as NPL was actually developed by the IMF in the framework of the Financial Soundness Indicators (FSIs) endorsed by the IMF Executive Board. On March 2006, the Financial Compilation Indicators stated that loan would fall under the non-performing loan when the payment of its principal and interest had passed the due date by the period of 3 months or 90 days or more. Non-performing loan can also be defined as an interest payment, which is the same as 3 months or 90 days interest or more that has been capitalized, refinanced, or rolled over. The 3 months or 90 days criterion is the time period that is most widely used by the countries to determine whether or not a loan is non-performing.

Andrew Crockett (2003) argues that originally non-performing loans (NPL) may not appear to have a severe negative result. Banks remain liquid and depositors maintain their confidence in the system. Over time, however, the size of the problem grows, especially if banks are allowed to accrue interest on their non-performing loans (NPL). Besides that, (Zeng, 2012), in his paper supports the following hypothesis by considering the situation in China: the equilibrium value of the bank NPL is dependent on micro-economic factors but influenced by macro-economic factors include the degree of openness to the outside world and government policy. Based on the model, to obtain a decrease in the NPLs in China, the banks' internal management effort must be enhanced. Likewise, the share structure of property rights should reform, decreasing the hidden guarantees that the government supplies, as well as decreasing asymmetric and imperfect information.

Furthermore, (Washington, 2012) in his paper the macroeconomic environment is viewed as a critical driver for nonperforming loans. The study found that Domestic credit and inflation to private sector by the commercial banks was found negative and related to credit risk. However, lending interest rates were positive and significant to credit risk.

The SNA 1993 (Statistical National Account) defined the principles for every country to follow, rather than to make a specific recommendation for country accounting standards. The principle of the non-performing loans is therefore, to clearly state the loans given the fact that contractual payments may not be done and also to identify the potential losses to both income and capital.

\subsection{Customer Standard of Living}

Based on gaps in literature, the researchers have hypothesized four (4) variables that seem to influence non-performing loans. The first element that the researchers have found is customer's standard of living. The customer's standard of living has a direct effect to non-performing loan (NPL). The reason underlays this argument is that nowadays, products such as electronic goods like Smartphones - Samsung products such as Samsung Galaxy series, Note series, and Apple products like - I Phone, I Pad, etc - are rampantly available and highly used in daily life. This phenomenon has set off a continual upgrading of the function, usage, design of the products by the producers on an annual basis to be launched in the following year as brand new versions. As the result, customers will keep purchasing the newest version of smartphones available in the market every year. 
This, the same time, will affect the customer's financial management. This will also cause the people to be unable to pay off loan interest to the bank if they apply for a loan from the bank to do the purchase (Aro \& Wilska, 2014).

\subsection{Consumer Income}

Customer's income has a direct relationship with non-performing loan. If the customer's income is neither low nor high and, they need to purchase a house and a cars they might require borrowing money from the bank. But at the same time, the loan might go default easily because the spending is higher than the earning (Grimsley, 2013).

\subsection{Bank Interest Rate}

Bank Interest rate can generally be defined as the profit of the bank earned from the customers by borrowing the customers' money. For instance, if Hong Leong Bank lend Stevie one hundred dollar with twenty percent interest. It means that Stevie has to return one hundred and twenty dollar to the bank. The twenty percent imposed on the loan principal is called Bank interest rate.

Apart from the simple bank interest rate, there is also compound interest imposed by the bank to the customers. Normally, compound interest rate is subject to customer who borrow a large sum of money from the bank and the loan is over a long time periods. For example, car loan and housing loan.

Furthermore, Bank interest rate can also be apply in the saving and certificates of deposit. It is like when people put their money into saving accounts or certificate of deposit, the bank will use the money to do investment to earn profit in the sense that the bank is actually borrowing money from the customers to generate profit through investment. Which is why the bank is giving some amount of interest to the accounts.

In addition, Bank interest rate can also be apply in the loans, mortgage and credit cards issued by commercial bank. Usually, pressure on businessmen and households - comes from the interest rate accruing in their loans, mortgage and credit cards. Looking into the commercial loan itself, it is a common platform for a small company to pump in capital into their business in order to generate profit and to spur company improvement and growth. For a household or a consumer, it is very common to apply for car loans, credit cards and mortgage from commercial banks - as this is the legal way for them to borrow money. Theoretically, if the interest rates have decreased, the consumers will refinanced their house to get a lower interest rate on their mortgage loan, for more affordable housing payment (Feigenbaum, 2012).

\subsection{Economy of the Country}

There are four main categories under the economic system, market economy, mixed economy, traditional economy and lastly command economy.

This type of economic system usually relies on the social customs. Some countries in Asia and Africa for instance, still support traditional economy by developing agricultural villages. Tradition defines the way of life livelihood, shelter, clothing a generation has, which is same as the previous generation. In simple words, in traditional economic system, the customs, value, belief and way of life adopted by the previous generation still shape the economy of the current generation.

In this type of economy, the consumer follow their own opinion or decision to purchase goods and services, and hardly follow the decision of the government. At the same time, the suppliers can decide the types and quantity of the products to produced and determine the best production method to be applied. In a complete market economic, the price of goods and services not controlled or subsidized by the government. Governments is only in charge on creating a stable economy for the market to operate properly.

Alternatively, in a command economic system, all economic activities are organized by government who makes all decision that the people must follow. Meanwhile, mixed economic system is a system consisting of a mixture or combination of market economy and also command economy. Malaysia is one of the example of countries adopting mixed economy system (Griffin, 2013). 


\subsection{Proposed Framework}

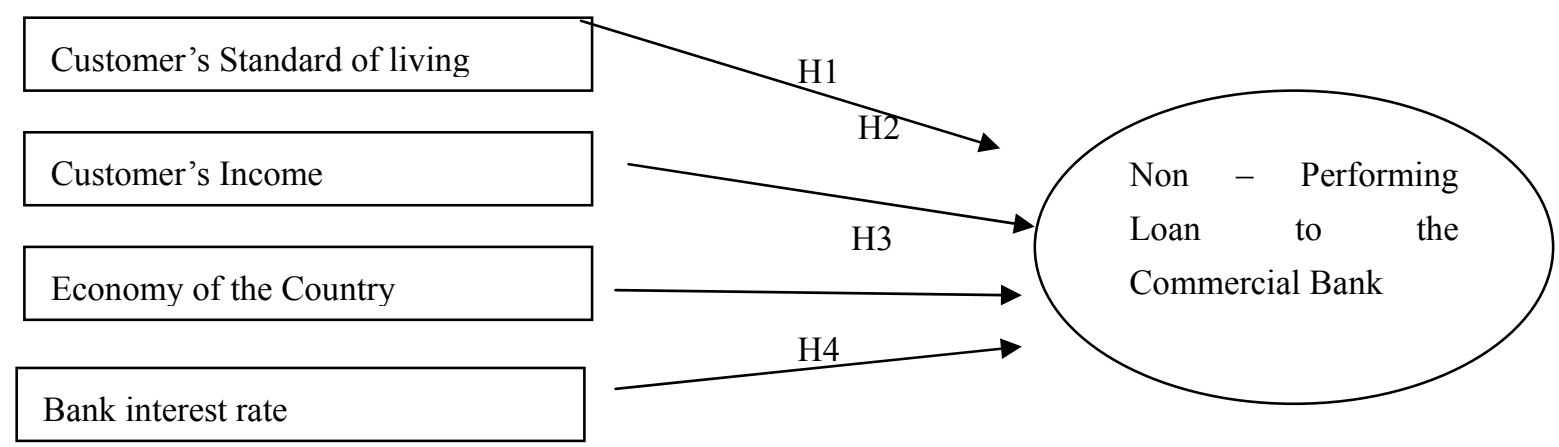

\subsection{Research Hypotheses}

H1: Customer's standard of living will have a direct significant influence on non-performing loans to commercial banks in Malaysia

H2: Customer's income will have a direct significant influence on non-performing loans to commercial banks in Malaysia

H3: Economy of the country will have a direct significant influence on non-performing loans to commercial banks in Malaysia

H4: Bank interest rate will have a direct significant influence on non-performing loans to commercial banks in Malaysia

\section{Research Methodology}

\subsection{Measurement and Collection of Data}

A quantitative research approach is employed in this research following the positivist assumption with a realist ontology and objectivist epistemology. Data was collected using a probabilistic sampling method, particularly a stratified random sampling technique.

The adapted survey questionnaire employed in this study is divided into two sections; demography and scales of the four (5) underlying factors of the research instrument, capturing four (4) independent variables and 1 dependent variables. A 5-point Likert scale was used showing (1)"strongly disagree", (2) "disagree", (3) "slightly agree", (4) "agree", (5) "strongly agree". The cronbach alphas of all 20 items in the scale shows 0.848 , above and over 0.7 cut off threshold (Sekaran \& Bougie) which suggest that the reliability of the scales for measuring standard of living, Consumer income, Economy of the country, Bank interest rate and non-performing loan are considered acceptable (Sekaran \& Bougie, 2010). Table 1 below captures the details of the adapted scales employed in this research.

Table 1. Adapted scales from previous studies

\begin{tabular}{ll}
\hline Variable & Source \\
\hline 1) Customer's standard of living & (Aro \& Wilska, 2014) \\
2) Customer's Income & (Grimsley, 2013) \\
3) Economy of the Country & (Griffin, 2013) \\
4) Bank Interest Rate & (Feigenbaum, 2012) \\
\hline
\end{tabular}




\subsection{Demography of Respondents}

Table 2. Gender, age, marital status, education level and income level

\begin{tabular}{llll}
\hline Types & Categories & Frequency & Percent \\
\hline \multirow{3}{*}{ Gender } & Male & 105 & 52.5 \\
& Female & 95 & 47.5 \\
& & & 6.5 \\
& 19 years old and below & 13 & 49.5 \\
Age & 20-35 years old & 99 & 33.0 \\
& $36-50$ years old & 66 & 11.0 \\
51 years old and above & 22 & 34.5 \\
Marital Status & Single & & 65.5 \\
& Married & 69 & 12.5 \\
& & 131 & 14.0 \\
Education Level & High School & & 70.0 \\
& Diploma & 25 & 3.5 \\
& Undergraduate & 28 & 17.0 \\
\end{tabular}

\subsection{Data Analysis}

\subsubsection{Correlation Analysis}

Table 3. Correlation analysis

\begin{tabular}{|c|c|c|c|c|c|c|c|}
\hline & & Nonperforming Loan & $\begin{array}{l}\text { Standard of } \\
\text { Living }\end{array}$ & $\begin{array}{l}\text { Consumer } \\
\text { Income }\end{array}$ & $\begin{array}{l}\text { Economy of The } \\
\text { Country }\end{array}$ & $\begin{array}{l}\text { Bank } \\
\text { Mate }\end{array}$ & Interest \\
\hline $\begin{array}{l}\text { Non-performing Loan } \\
\text { Correlation }\end{array}$ & Pearson & 1 & $.221 * *$ & $.358^{* *}$ & $.282 * *$ & $.576^{* *}$ & \\
\hline $\begin{array}{l}\text { Standard of Living } \\
\text { Correlation }\end{array}$ & Pearson & & 1 & $.497 * *$ & $.567 * *$ & .037 & \\
\hline $\begin{array}{l}\text { Consumer Income } \\
\text { Pearson Correlation }\end{array}$ & & & & 1 & $.531 * *$ & .094 & \\
\hline $\begin{array}{l}\text { Economy of The Country } \\
\text { Correlation }\end{array}$ & Pearson & & & & 1 & .002 & \\
\hline $\begin{array}{l}\text { Bank Interest Mate } \\
\text { Pearson Correlation }\end{array}$ & & & & & & 1 & \\
\hline
\end{tabular}

From table 3, it shows that the relationship between two variables. In the non-performing loan aspect, it displays the correlation of the relationship between non-performing loan and standard of living is 0.221

Secondly, under the relationship between non-performing loan and consumer income, based from the result, it shows that the non-performing loan has a low correlated relationship with the consumer income. In other words, it can be considered that both of the variables are not so relative to each other.

Thirdly, under the relationship between non-performing loan and economy of the country, based from the result, it shows that the non-performing loan is low correlated with the economy of the country. In other words, it can be considered as both of the variables are not so relative to each other.

Finally, under the relationship between non-performing loan and the bank interest rate based from the result it shows that the non-performing loan has a moderate correlated relationship with the bank interest rate. It means both variables are relative connected to each other. 


\subsection{Multiple Regression Analysis}

Table 4. Model summary

\begin{tabular}{llllll}
\hline Model & $\mathrm{R}$ & $\mathrm{R}$ Square & Adjusted R square & Std. Error of the Estimate & Durbin-Watson \\
\hline 1 & .667 & .445 & .433 & .53180 & 1.220 \\
\hline
\end{tabular}

a. Predictors: (Constant), Bank Interest Mate, Economy of The Country, Consumer Income, Standard of Living

b. Dependent Variable: Non-performing loan.

\subsection{Model Summary}

From the table 5, it shows that the Durbin Watson is 1.220. It indicates that the independent error terms are not correlated. Apart from that, R square also plays an important role in the model summary. The word R here can be defined as the strength of the relationship between the forecast and outcome from this research study measured. Based from the above table, it shows that the $\mathrm{R}$ square is 0.445 or 44.5 percent. It indicates that $44.5 \%$ of the total variance in the dependent variable (non-performing loan) is explained by the independent variables (standard of living, consumer income, economy of the country, and the bank interest rate). Hence, the remaining 55.5 percent is unaccounted for, which could be due to other variables which are not involved in this research study.

Table 5. ANOVAa

\begin{tabular}{|c|c|c|c|c|c|}
\hline Model & Sum of Squares & df & Mean Square & $\mathrm{F}$ & Sig \\
\hline Regression & 44.196 & 4 & \multirow{3}{*}{$\begin{array}{l}11.049 \\
.283\end{array}$} & \multirow{3}{*}{39.069} & \multirow{3}{*}{$.000 \mathrm{~b}$} \\
\hline Residual & 55.147 & 195 & & & \\
\hline Total & 99.344 & 199 & & & \\
\hline
\end{tabular}

a. Dependent Variable: Nonperforming Loan

b. Predictors: (Constant), Bank Interest Mate Economy of the Country Consumer Income, Standard of Living.

ANOVA table 5 shows a significant value (p-value $<0.05$ ) which implies the entire model has acceptable goodness-of-fit. At the same time, it also means that at least one of the independent variables (standard of living, consumer income, economy of the country, and bank interest rate) is able to significantly influence the dependent variable (non-performing loan). The coefficient table provides the details of significance levels of each variables.

Table 6. Coefficients A

\begin{tabular}{|c|c|c|c|c|c|c|c|}
\hline \multirow[t]{2}{*}{ Model } & \multicolumn{2}{|c|}{ Unstandardized Coefficients } & \multirow{2}{*}{$\begin{array}{l}\text { Standardized } \\
\text { Coefficient } \\
\text { Beta }\end{array}$} & \multirow[t]{2}{*}{$\mathrm{t}$} & \multirow[t]{2}{*}{ Sig. } & \multicolumn{2}{|c|}{ Collinearity Statistics } \\
\hline & $\mathrm{B}$ & Std. Error & & & & Tolerance & VIF \\
\hline (Constant) & -.303 & .344 & & -.880 & .380 & & \\
\hline Standard of Living & -.002 & .065 & -.002 & -.035 & .972 & .625 & 1.599 \\
\hline Consumer Income & .214 & .064 & .219 & 3.319 & .001 & .655 & 1.528 \\
\hline Economy of the Country & .172 & .072 & .166 & 2.397 & .017 & .594 & 1.684 \\
\hline Bank Interest Mate & .681 & .066 & .555 & 10.347 & .000 & .988 & 1.012 \\
\hline
\end{tabular}

a. Dependent Variable: Non-performing Loan.

The "sig" column labels that whether the variables are important or not. Also, the significance value should be less than 0.05 . According from the table 5 , it shows that there is a variable is not significant because the $\mathrm{p}$-value is larger than 0.05 . This variable is standard of living with p-value of 0.972 . But, other variables are significant whereby the p-value is less than 0.05 ; these variables are consumer income, economy of the country, bank interest rate with the value of $0.001,0.017$, and 0.000 .

Based on the table 5 , the following equation is generated:

Non- performing loan $=-0.303+-0.002$ (standard of living) +0.214 (consumer income) +0.172 (Economy of the country) +0.681 (bank interest rate)

This regression equation is represented that the unit decrease in standard of living decrease non-performing loan. 
However, it also shows that the unit increase in consumer income increase non- performing loan by 0.214 , a unit increase in economy of the country increase non-performing loan by 0.172 and a unit increase in bank interest rate increase non-performing loan by 0.681 .

In the coefficients table, the VIF value plays an important role in the collinearity statistics as well. The VIF value should be less than 10 so that it is no multicollinearity. From above the table, it indicates that the VIF value is 5.823 which is lesser than the 10 . Therefore, it can be considered as there is no multicollinearity.

\subsection{Hypotheses Result}

\begin{tabular}{|c|c|c|c|c|}
\hline & Hypothesis & Sig & Result & $\begin{array}{l}\text { Gradient (Beta, } \\
\beta)\end{array}$ \\
\hline $\mathrm{H}_{1} 1$ & $\begin{array}{l}\text { The customer's standard of living and the non-preforming loan reflect a direct } \\
\text { significance and correlation. }\end{array}$ & 0.972 & $\begin{array}{l}\text { Not } \\
\text { supported }\end{array}$ & -0.002 \\
\hline $\mathrm{H}_{1} 2$ & $\begin{array}{l}\text { The consumer's income and the non-performing loan reflect a direct significance and } \\
\text { correlation. }\end{array}$ & 0.001 & supported & 0.214 \\
\hline $\mathrm{H}_{1} 3$ & $\begin{array}{l}\text { The economy of the country and non-performing loan reflect a direct significance and } \\
\text { correlation. }\end{array}$ & 0.017 & Supported & 0.172 \\
\hline $\mathrm{H}_{1} 4$ & $\begin{array}{l}\text { The bank interest rate and non-performing loan reflect a direct significance and } \\
\text { correlation. }\end{array}$ & 0.000 & Supported & 0.681 \\
\hline
\end{tabular}

\section{Discussion of Findings}

In this research, there are 200 respondents have filled in the questionnaire. Most of the respondents are from the age range of 20-35 years old, married status, income level under RM2500-RM3999, Education level undergraduate. Under the pilot study test, the reliability test result is 0.807 which means it shows ideal.

\subsection{Result of the Correlation and Multiple Regression Analysis}

These results are came from 200 respondents and analyzed by SPSS. In the correlation test, there has Pearson correlation of non-performing loan. Non-performing loan has a weak relationship with the standard of living, consumer income, and economy of the country, however it has a moderate relationship between the bank interest rate.

In the multiple regression analysis, there have model summary, AVOVA and coefficient table. Durbin- Watson is 1.220 in the model summary; it means the value is considered as an ideal value. R square in the model summary is $44.5 \%$, it means $44.5 \%$ of the independent variables will affect the dependent variable. The significant value for ANOVA is 0.000 , so it is consider ideal value because the result should not be more than 0.05 , once it's beyond the amount, it is not accepted. Consumer income, economy of the country, bank interest rate will be accepted because the results are less than 0.05 . Therefore, the null hypothesis of these variables is accepted.

\subsection{Implication of the Study}

This research study is to study about the factors of non-performing loan in the commercial bank. There are 4 factors such as standard of living, consumer income, economy of the country, and bank interest rate. The implication of this study will influence the commercial banks, borrowers and future researchers.

For the commercial bank, they will receive important information from this research study. The bank will found that the bank interest rate affect the rate of non-performing loan increase. For the future researchers, this research will benefit them as well. If they are doing their researches which are related to this topic, they can gather everything they want easily. Besides that, it will benefit the researcher who is going to this research study in Malaysia. This is because the information in Malaysia is limited.

Lastly are the borrowers from the bank. In this research, the borrowers can get information of non-performing loan in the commercial bank. They will understand how the standard of living, income, economy and bank interest rate will affect in managing their debts.

\section{Recommendation for the Future Research}

Many works are still required on the investigation of the factors of non-performing loan and their relationship with the commercial banks. The above information has indicated thatthe 4 factors -standard of living, consumer income, economy of the country, bank interest rate- affect non-performing loan to various extents.

The researchers found that 3 independent variables such, i.e. consumer income, economy of the country and 
bank interest rate, support the dependent variable. meanwhile, one independent variable does not support the dependent variable.

For future research, therefore, it is advisable to increase the size of the samples due to the fact that more surveys may yield more accurate findings. The future researchers can also use this research as a reference more reliable and useful study in the future.

\section{Conclusion}

Overall, the researcher has discussed about the findings of the analysis that was conucted using the SPSS software. Descriptive approach, correlation and multiple regression analysiss had been shown during the analysis The descriptive approach displayed direct results while the correlation displayed the relationship between the dependent variable (non-performing loan) and the independent variables (standard of living, consumer income, economy of the country, bank interest rate). In addition, the researcher also mentioned the model summary, ANOVA and coefficient table in the multiple regressions. The researcher had also discussed about the implication and limitations of this study. Lastly, the researcher had provided some recommendations for future researchers who will do research of similar topics.

\section{References}

Adriaan, M., \& Bloem, R. F. (2005). The Treatment of Nonperforming Loans. Statistics Department.

Ahlem Selma Messai, F. J. (2013). Micro and Macro Determinants of Non-performing Loans. International Journal of Economics and Financial Issues, 853-855.

Aremu, O. J. (2010). Effective Credit Processing and Administration as a Panacea for Non-performing Assets in the Nigerian Banking System. Department of Banking and Finance, The Polytechnic, Ibadan, Nigeria.

Balasubramaniam, C. S. (2001). Non Performing assets and profitability of commercial banks in india: assessment and emerging issues. Babasaheb Gawde Institute of Management Studies, 42-46.

Bank, T. W. (2015). Malaysia Non-performing loans. Retrieved April 2, 2015, from http://www.theglobaleconomy.com/Malaysia/Nonperforming_loans/

Barseghyan, L. (2005). Non-Performing Loans, Prospective Bailouts, and Japan's Slowdown. Apartment of Economics, Northwestern University, 6-7.

Bernardo Maggi, M. G. (2009). Modeling Non- Performing Loan probability to the Commercial Banking system. Dipartimento di Economia, 1-10.

Boyd, N. (2015). What is Sampling in Research? - Definition, Methods \& Importance. Retrieved April 1, 2015 , from http://study.com/academy/lesson/what-is-sampling-in-research-definition-methods-importance.html

Defining the Sample and Collecting Data. (n.d.). Retrieved from https://www.boundless.com/sociology/textbooks/boundless-sociology-textbook/sociological-research2/the-research-process-26/defining-the-sample-and-collecting-data-169-5911/

Definition of Linearity. (n.d.). from http://www.chegg.com/homework-help/definitions/linearity-31

Descriptive and Inferential Statistics. (n.d.). Retrieved from https://statistics.laerd.com/statistical-guides/descriptive-inferential-statistics.php

Descriptive Statistics. (n.d.). Retrieved from http://www.socialresearchmethods.net/kb/statdesc.php

Dimitrios, P., \& Louzis, A. T. (2011). Macroeconomic and bank-specific determinants of non-performing loans in Greece: A comparative study of mortgage, business and consumer loan portfolios. Journal of Banking and Finance, 3-6.

Feigenbaum, E. (2012). The Meaning of Interest Rate. Retrieved April 1, 2015, from http://smallbusiness.chron.com/meaning-interest-rate-3650.html

Griffin, D. (2013). Economic System Types. Retrieved April 1, 2015, from http://smallbusiness.chron.com/economic-system-types-1129.html

Grimsley, S. (2013). Consumer Income: Definition, Statistics \& Quiz. Retrieved April 1, 2015, from $\mathrm{http} / /$ study.com/academy/lesson/consumer-income-definition-statistics-quiz.html 
Hou, Y. (n.d.). The Non-performing Loans: Some Banks level evidence.

Irum Saba, R. K. (2012). Determinants of Non-performing loan: Case of US sector. The Romanian Economic Journal, 142-146.

Islam, M. S., \& Md., N. C. (2005). Non performing loans-its causes. Munich Personal RePEc Archive, 2-5.

Kauko, K. (2011). External Deficits and Non Performing Loan in the recent financial crisis.

Kevin Greenidge, T. G. (2009). Forecasting non-performing loans in barbados. Research DepartmentCentral Bank of Barbados, 2-4.

Klein, N. (2013). Non-Performing Loans in CESEE: Determinants and Impact on Macroeconomic. IMF Working Paper, 5-7.

Kolapo, T. (2012). Credit risk and commercial bank performance in Nigeria. Australian Journal of Business Management Research, 32-34.

Mohamed Adam, H. (2014). Research population. Retrieved from Academia: http://www.academia.edu/5563491/Research_Population

Muhammad Farhan, A. S. (2012). Economic Determinants of Non-Performing Loans: Perceptions of Pakistan Bankers. European Journal of Business and Management, 88-92.

Mukesh Kumar, S. A. (2013). Sampling Design: Theory and Practice. New York: Oxford Fajar.

Multiple Regression Analysis. (n.d.). Retrieved from https://explorable.com/multiple-regression-analysis

Muriithi, M. W. (2013). The causes of non-performing loans in. A Research Project Report, 2-4.

Nau, R. (2014). Notes on linear regression analysis. 1.

Nkusu, M. (2011). Nonperforming Loans and Macrofinancial Vulnerabilities in Advanced Economies. IMF Working Paper, 2-8.

Nkusu, M. (2011). Nonperforming Loans and Macrofinancial. International Monetary Fund.

Nonperforming Loan-NPL. (n.d.). Retrieved April 1, 2015, from http://www.investopedia.com/terms/n/nonperformingloan.asp

Nor Farradila binti Abdul Aziz, I. B., \& Kamaruddin, M. B. (2009). The Impact of Nonperforming towards Profitability Performance. Malaysia: Faculty of Business Management Universiti Teknologi Mara.

Nuttall, L. (2011). 1 in 4 web users bank online every day. Retrieved fromhttp://www.thinkmoney.co.uk/news-advice/one-in-four-web-users-bank-online-every-day-0-3769 $-0 . h$ tm

Pacha Malyadri, S. S. (2011). A Comparitive of Non performing Assets in India Bank Industry. International Journal of Economies Practices and Theories, 77-80.

Parke, C. S. (2013). Essential First Steps to Data Analysis. California: SAGE .

Peiser, R. (2002). Non-Performing loan Resolution in China. Journal of Real Estate Porfolio Management, 117-118.

Perkins, E. Z. D. (2013). Factors affecting the Adoption of Online Banking in Ghana: Implications for Bank Managers. International Journal of Business and Social Research.

POPULATIONS AND SAMPLING. (n.d.). Retrieved from University of Missourri.

Rajiv Ranjan, S. C. (2003). Non-Performing Loans and Terms of Credit of Public Sector Banks in India. Bank of India Occasional Papers, 83-89.

Raphael Espinoza, A. P. (2010). Nonperforming Loans in the GCC Banking System and their Macroeconomic Effects. IMF Working Paper, 6-8.

Reliability. (n.d.). Retrieved from Research http://www.socialresearchmethods.net/kb/reliable.php

Research population. (n.d.). Retrieved from https://explorable.com/research-population

Riikka, A. T. A. W. (2014). Standard of living, consumption norms, and perceived necessities.

Roland Beck, P. J. (2013). Non-Performing Loan What Matters in Addition to the Economic Cycle. European Central Bank Euro system, 5-8.

Sampling. (n.d.). Retrieved from http://www.socialresearchmethods.net/kb/sampling.php 
Shahbaz Haneef, T. R. (2012). Impact of Risk Management on Non-Performing Loans and Profitability of Banking Sector of Pakistan. International Journal of Business and Social Science, 307-314.

Sofoklis, D., \& Vogiazas, E. N. (2011). Investigating the Determinants of Nonperforming Loans in the Romanian Banking System. Hindawi Publishing Corporation Economics Research International, 4-6.

Tracey, M. (2011). The Impact of Non-performing Loans on Loan Growth: an econometric case study of Jamaica and Trinidad and Tobago.

Warue, B. N. (2012). Factors on Nonperforming Loans in Commercial Banks in Kenya. Scienpress Ltd .

William M.K. Trochim. (2006). Reliability. Retrieved from http://www.socialresearchmethods.net/kb/reliable.php

Woods, L. (2014). The History of Online Banking. Retrieved fromhttp://www.gobankingrates.com/banking/history-online-banking/

Yount, R. (2006). Populations and Sampling.

Zeng, S. (2012). Bank Non-Performing Loans (NPLS): A Dynamic Model and Analysis in China. Journal of Scientific Research, 3-4.

\section{Copyrights}

Copyright for this article is retained by the author(s), with first publication rights granted to the journal.

This is an open-access article distributed under the terms and conditions of the Creative Commons Attribution license (http://creativecommons.org/licenses/by/4.0/). 